\title{
Methods And Forms of Teaching of the Right To Information by Shareholders in the Digital Economy
}

\begin{abstract}
Aleksey I. Ovchinnikov ${ }^{1}$, Yana B. Getman ${ }^{2}$, Irina V. Kolesnik ${ }^{3}$, Veronika V. Kolesnik ${ }^{4} \&$ Natalia A. Boyko $^{5}$
${ }^{1}$ Doctor of Legal Sciences, Professor, Professor of the Department of Theory and History of State and Law of the South Federal University; Professor of the Department of Theory and History of State and Law of the Rostov Branch of the Russian State University of Justice; Professor of the Department of Constitutional and Municipal Law of the Russian Presidential Academy of National Economy and Public Administration, Professor of the Department of Constitutional and Administrative Law of the Institute of Service, Tourism and Design (branch) of the Federal State Autonomous Educational Institution of Higher Education «North Caucasus Federal University», Russian Federation.

${ }^{2}$ Professor of the Department of Civil Law of the Rostov Branch of the Russian State University of Justice.

${ }^{3}$ Professor of the Department of Civil Law of the Rostov Branch of the Russian State University of Justice (344038, Rostov-on-Don, 66 Lenin Str. \& Doctor of Legal Sciences, Associate Professor.

${ }^{4}$ Professor of the Department of Civil Law of the Rostov Branch of the Russian State University of Justice (344038, Rostov-on-Don, 66 Lenin Str., PhD of Legal Sciences.

${ }^{5}$ Head of the Department of Constitutional and Administrative Law of the Institute of Service, Tourism and Design (branch) of the Federal State Autonomous Educational Institution of Higher Education «North Caucasus Federal University», Candidate of Legal Sciences, Associate Professor (Pyatigorsk, Email - boikonatali@mail.ru). Head of the Department of Constitutional and Administrative Law of the Pyatigorsk Branch of the North Caucasus Federal University, PhD in Law, Associate Professor.

Correspondence: Aleksey I. OVCHINNIKOV, Doctor of Legal Sciences, Professor, Professor of the Department of Theory and History of State and Law of the South Federal University; Professor of the Department of Theory and History of State and Law of the Rostov Branch of the Russian State University of Justice; Professor of the Department of Constitutional and Municipal Law of the Russian Presidential Academy of National Economy and Public Administration, Professor of the Department of Constitutional and Administrative Law of the Institute of Service, Tourism and Design (branch) of the Federal State Autonomous Educational Institution of Higher Education «North Caucasus Federal University», Russian Federation. E-mail: k_fp3@mail.ru
\end{abstract}

Received: July 17, 2019

doi:10.5430/ijhe.v8n7p138
Accepted: October 15, 2019

Online Published: October 28, 2019

\begin{abstract}
Joint stock issues, i.e. legal rules governing relations within commercial corporations, attract special attention of researchers of private law, corporate law in particular. A large number of internal corporate contradictions plays a negative role in the economic and economic activities of joint-stock companies. This fact affects the growth in the number of scientific publications on the issues of shareholder relations between their participants in terms of compliance with the civil law prohibition of Teaching of the right. It also has an impact on judicial practice: more and more often, the courts use the term "Teaching of law" to analyze existing conflicts in corporate law.
\end{abstract}

Keywords: teaching of right, shareholder legal relations, subjects of teaching of right in shareholder legal relations, corporate blackmail

\section{JEL Classification Code (up to 3-5)}

\section{Introduction}

Legal science emphasizes the importance of the right to information in the structure of shareholder relations. This right is protected not so much by the Law on Joint-Stock Companies, but also paragraph 1 of Article 6 of the Law "On the Protection of the Rights and Lawful Interests of Investors on the Securities Market" (Federal law of 08.02.1998 N 14-FZ). It specifies the obligation to provide the necessary information to the investor-shareholder: "The issuer is obliged to provide the investor with information determined by the legislation of the Russian Federation". 
In addition to shareholders, other participants in joint-stock companies, for example, trustees, also have the right to information.

There are quite a few examples in practice when shareholders, through their actions, did great harm by acquiring a small number of shares, and subsequently demanding a copy of a large number of documents. Among these documents may be, for example, voting ballots for several years, minutes of shareholders' meetings, and many more in the amount of several thousand copies.

Options shareholder information with several. Option One: the study of information published on a mandatory basis in accordance with the legislation governing the activities of joint-stock companies (Law on Joint-Stock Companies). Option two: information about the joint-stock company, its activities are sent by the shareholder even without their requirements in connection with the forthcoming general meeting of shareholders in the course of preparation for it.

The third option arises in the case of a shareholder sending the requirement to provide documentation in accordance with the stated list and list of its categories. The next option is an addition to the previous one: in case the shareholder has 25 percent of the voting shares, he is entitled to receive accounting information, information on the minutes of meetings of the collegial executive body (paragraph 1 of Article 91 of the JSC Law).

A shareholder may initiate a request for information on the activities of a joint stock company. However, there are situations when the joint stock company itself sends the required information to the mailing list or requires information. The legislation obliges to provide the shareholder with the required information. Article 91 is devoted to this, considering the mechanisms by which the company provides information to shareholders (Federal law of 08.02.1998 N 14-FZ) In accordance with paragraph 1 of Art. 67 of the Civil Code of the Russian Federation, participants in a joint-stock company have the right to receive information on the company's activities and to familiarize themselves with its accounting books and other documentation in accordance with the established constituent documents.

The list of documents can be supplemented with the help of the charter, decisions of the general meeting of shareholders, its governing bodies. The information letter of the President of the Supreme Court of Arbitration of the Russian Federation of January 18, 2011 No. 144 "On some issues of the practice of considering disputes on provision of information by arbitration courts by participants of economic societies" providing information about the company, participants should determine the subject of their requirements, specifying the list and types of information requested or documents.

The shareholder is not obliged to explain the reasons and motives of his requests, there is no limit in terms of the period for which the shareholder may request information. Teaching of the law in the process of obtaining information may occur in the course of obtaining and further dissemination of the information received (Millanei et al, 2016; Jaramillo, 2018).

Specialist in the field of joint stock law I.T. Tarasov believes that when determining the scope of the rights of a participant in a joint-stock relationship, the following factors should be kept in mind: first, the degree of difficulty in managing the joint-stock company and in exercising management responsibilities; secondly, in what and to what extent, in case of Teaching of the right to information by shareholders, there may be losses and harm to the company (Lee \& Cormier, 2010; Tarasov, 2000; Kolosovskaya \& Zharkaya, 2015; Krokhina, 2015; Akimzhano et al, 2018).

It seems to be the correct position of some authors regarding the obligation of a shareholder to keep a commercial secret in case of leaving the joint-stock company (Kolosovskaya \& Zharkaya, 2015; Krokhina, 2015; Tarasov, 2000). The time period, in this case, can be set, in our opinion, the documents of the statute. It should also require the shareholder to specify the purpose and legitimate interests that dictate the need to request certain information. In rare cases, a minority shareholder may require information containing trade secrets.

To understand the economic development of a society, it is hardly necessary to have knowledge of the production secret. It seems necessary, in our opinion, to make proposals to legislation, according to which, the right to receive information on the activities of a joint stock company containing a trade secret belongs to a person who has at least half $(50 \%)$ of voting shares. Thanks to this rule, this information will be available only to those shareholders who have a decisive influence on the policy of the joint stock company.

\section{Research Methods and Materials}

Shareholder Teaching can manifest itself in various forms. Consider different forms in sequence. First of all, the Teaching can manifest itself in the form of the frequency of requests and claims that are sent to the joint-stock company. Abusive members may send their requests too often. 
At the same time, the joint-stock company is forced to constantly collect documents, which inevitably turns out to be at the work of the joint-stock company, more precisely, its employees. After all, requests must be received within seven days from the date of presentation to their shareholder. Some authors believe that "the real reason for the frequent direction is evidence of the desire to destabilize the work of society, to create conditions that can adversely affect the economic activity of the company" (Kolosovskaya \& Zharkaya, 2015; Krokhina, 2015; Tarasov, 2000; García-Santillán, 2019).

In judicial practice, there is a case where a shareholder often sent requests for documents of various informational nature. The court pointed out that the fact that a shareholder repeatedly applied for a very short period of time requires special attention, since requests may be of a non-diligent nature in order to destabilize the company's work.

In the case of a court decision on the possibility of not providing a legal entity with information by an unscrupulous shareholder, the latter does not waive the right to continue to forward requests for information. There is also no obligation to pay damages caused by Teaching of the right. You can indicate the need in terms of optimizing legislation to establish the frequency of general duties of shareholders.

For example, it is possible to define such a period once a year. However, it is impossible to destroy the shareholder's right to request more often information, therefore, if necessary, the shareholder can explain his informational appeal.

Teaching of law may be in other cases. A shareholder may prepare and send a request for documents that contain a trade secret.

In addition, information may be required for a very long period. In the latter case, it is necessary to point out that some documents are stored for a very long period in the archive: annual reports, voting records. Within seven days, it is also very difficult to find documents and deliver.

Judicial practice is experienced in satisfying shareholders 'claims on receiving information from the past five years. It is during this period that the company keeps the documents. It is possible, in our opinion, to propose the inclusion in the Federal Law on JSC a provision on accessibility in the last five years of work. A longer period should be accompanied by an explanation of the purpose and motives of the shareholder.

A special case of Teaching of the right is a request for documents in which a trade secret is hidden. After all, there is always the danger of disclosing the information received. Moreover, this can be done, either intentionally or through carelessness due to careless storage. Therefore, joint stock companies do not very often carry out such requests for information.

Such cases are easily resolved in the courts if there is evidence that the shareholder is not a bona fide person who has previously disclosed a trade secret. But it is very difficult to do in the absence of goals and harmful intent of the shareholder.

Shareholders are required to keep confidential documents about the activities of the organization in secret. According to the position of the Presidium of the Supreme Arbitration Court, expressed in the information letter dated January 28,2011 . "On some issues of the practice of arbitration courts considering disputes on providing information to participants of business societies" has the right to require writing a receipt-obligation to keep the confidential information received in secret.

However, the legislation does not indicate the relationship of such a receipt with the obligation of the shareholder to keep information secret. Meanwhile, as a result of disclosure of information containing a commercial secret, a joint-stock company may incur very serious losses. Their shareholder is obliged to compensate in accordance with Article 1472 of the Civil Code of the Russian Federation. Meanwhile, it is extremely difficult to prove that this information was disclosed by this shareholder.

It seems to be the correct position of some authors regarding the obligation of a shareholder to keep a commercial secret in case of leaving the joint-stock company (Kolosovskaya \& Zharkaya, 2015; Krokhina, 2015; Tarasov, 2000). The time period, in this case, can be set, in our opinion, the documents of the statute. It should also require the shareholder to specify the purpose and legitimate interests that dictate the need to request certain information. In rare cases, a minority shareholder may require information containing trade secrets.

To understand the economic development of a society, it is hardly necessary to have knowledge of the production secret. It seems necessary, in our opinion, to make proposals to legislation, according to which, the right to receive information on the activities of a joint stock company containing a trade secret belongs to a person who has at least half $(50 \%)$ of voting shares. Thanks to this rule, this information will be available only to those shareholders who have a decisive influence on the policy of the joint stock company. 
A few words should be said about the Teaching of the right to information at the place of familiarization with it. According to the legislation, the requested documents are provided to the shareholder for examination at the company's premises.

However, such premises may also be residential real estate, as registration can be implemented, in accordance with paragraph 4 of the Resolution of the Presidium of the Supreme Arbitration Court of the Russian Federation of July 30, 2013 No. 61 "On some issues of the practice of resolving disputes related to the accuracy of the legal entity's address" (Resolution of the Plenum of the Supreme Arbitration Court of the Russian Federation of July 30, 2013 N 61). Consequently, the shareholder requesting information can expect to get acquainted with the information in this room. It would be correct, in our opinion, to give freedom of choice to the executive bodies of the joint-stock company in the premises in which the shareholder will get acquainted with the documents. This information can be posted on the website of the joint stock company. Regarding the terms of familiarization, it should be noted that the shareholder can get acquainted with the documents he needs as long as he wishes, since the law does not regulate this period. A shareholder may delay the return of documents. Therefore, the term must have a reasonable activity, justified by the object provided by the information. Such a rule can be included in the legislation: the period for familiarization is set based on the volume of the documents provided and can be extended at the request of the shareholder.

In one of the court cases it was stated that in accordance with paragraph 1 and 2 of Art. 91 of the Federal Law "On Joint-Stock Companies", the company must guarantee to shareholders the receipt of the documents specified in paragraph 1 of Art. 89 of the Federal Law "On Joint Stock Company". The joint-stock company issues this information contained in these documents for acquaintance in the seven-day period from the moment the request for information is made for review at the premises of the company's management body. Copies of these documents must be provided by the company at the request of interested parties. At the same time, the cost of familiarization with copies consists only of the cost of their manufacture. As indicated in paragraph 1 of Art. 8 and p. 2 of Art. 50 of the Federal Law "On LLC" (Federal Law dated February 8, 1998 N 14-FL (as amended on December 29, 2015) "On Limited Liability Companies") shareholders have the right to access information about the company's activities, accounting books, other documentation in the order stipulated by its constituent documents. The storage of these documents is carried out where its sole executive body is located, as indicated in paragraph 1 of Art. 50 FL "On LLC". This place should be accessible to members of the LLC.

\section{Results and Discussion}

There are quite a few examples in practice when shareholders, through their actions, did great harm by acquiring a small number of shares, and subsequently demanding a copy of a large number of documents. Among these documents may be, for example, voting ballots for several years, minutes of shareholders' meetings, and many more in the amount of several thousand copies.

One of the options for Teaching of the right to information in the legal relationship between a shareholder and a joint-stock company is the Teaching of the shareholder's right to receive information about the activities of the joint-stock company. Shareholders, as is known, by virtue of paragraph 1 of article 65.2 of the Civil Code of the Russian Federation acquire certain rights and obligations in relation to a joint stock company, including the right of shareholders in cases and in accordance with the procedure established by the legislation and constituent documents, to have access to information on joint stock company activities. society, get accounting and other documentation.

Options shareholder information with several. Option One: the study of information published on a mandatory basis in accordance with the law governing the activities of joint stock companies (JSC Law). Option two: information about the joint-stock company, its activities are sent by the shareholder even without their requirements in connection with the forthcoming general meeting of shareholders in the course of preparation for it.

The third option arises in the case of a shareholder sending the requirement to provide documentation in accordance with the stated list and list of its categories. The next option is an addition to the previous one: in case the shareholder has 25 percent of the voting shares, he is entitled to receive accounting information, information on the minutes of meetings of the collegial executive body (paragraph 1 of Article 91 of the JSC Law).

A shareholder may initiate a request for information on the activities of a joint stock company. However, there are situations when the joint stock company itself sends the required information to the mailing list or requires information. The legislation obliges to provide the shareholder with the required information. Article 91 is devoted to this, considering the mechanisms by which a company provides information to shareholders (Federal Law of December 26, 1995 No. 208-FL, 1996). In accordance with paragraph 1 of Art. 67 of the Civil Code of the Russian 
Federation, participants in a joint-stock company have the right to receive information on the company's activities and to familiarize themselves with its accounting books and other documentation in accordance with the established constituent documents.

The list of documents can be supplemented with the help of the charter, decisions of the general meeting of shareholders, its governing bodies. The information letter of the President of the Supreme Court of Arbitration of the Russian Federation of January 18, 2011 No. 144 "On some issues of the practice of considering disputes on provision of information by arbitration courts" participants of economic societies "states that when applying to the economic society with a request to provide information about the company, participants must determine the subject of their demand specifying the list and types of requested information or documents.

The shareholder is not obliged to explain the reasons and motives of his requests, there is no limit in terms of the period for which the shareholder may request information. Teaching of the law in the process of obtaining information may occur in the course of obtaining and further dissemination of the information received.

Shareholder Teaching can manifest itself in various forms. Consider different forms in sequence. First of all, the Teaching can manifest itself in the form of the frequency of requests and claims that are sent to the joint-stock company. Abusive members may send their requests too often.

At the same time, the joint-stock company is forced to constantly collect documents, which inevitably turns out to be at the work of the joint-stock company, more precisely, its employees. After all, requests must be received within seven days from the date of presentation to their shareholder. Some authors believe that "the real reason for the frequent direction is evidence of the desire to destabilize the work of society, to create conditions that can adversely affect the economic activity of the company" (Kolosovskaya \& Zharkaya, 2015; Krokhina, 2015; Tarasov, 2000).

Repeated requests for information on the same documents or their copies may be the reason that the court may refuse the joint-stock company to an unfair participant. This was indicated in his information letter by the Supreme Arbitration Court of the Russian Federation (Resolution of the Plenum of the Supreme Arbitration Court of the Russian Federation of July 30, 2013 N 61, Resolution of the Federal Arbitration Court of the West Siberian District of March 9, 2011 in case No. A45-25123, 2009; Resolution of the Federal Arbitration Court of the Moscow District of March 6, 2012 in case No. A41-21750, Resolution of the Federal Arbitration Court of the Volga Region dated December 27, 2013 in case No. A55-5450, 2013; Resolution of the Federal Arbitration Court of the Volga Region dated December 27, 2013 in case No. A55-5450, 2013; Resolution of the Federal Arbitration Court of the West Siberian District of March 9, 2011 in case No. A45-25123, 2009; Resolution of the Federal Arbitration Court of the Moscow District of March 6, 2012 in case No. A41-21750).

In judicial practice, there is a case where a shareholder often sent requests for documents of various informational nature. The court pointed out that the facts of the repeated circulation of a shareholder within a very short period of time require special attention, since requests may be of a non-diligent nature in order to destabilize the work of the company.

In the case of a court decision on the possibility of not providing a legal entity with information by an unscrupulous shareholder, the latter does not waive the right to continue to forward requests for information. There is also no obligation to pay damages caused by Teaching of the right. You can indicate the need in terms of optimizing legislation to establish the frequency of general duties of shareholders.

For example, it is possible to define such a period once a year. However, it is impossible to destroy the shareholder's right to request more often information, therefore, if necessary, the shareholder can explain his informational appeal.

Teaching of law may be in other cases. A shareholder may prepare and send a request for documents that contain a trade secret.

In addition, information may be required for a very long period. In the latter case, it is necessary to point out that some documents are stored for a very long period in the archive: annual reports, voting records. Within seven days, it is also very difficult to find documents and deliver.

The Presidium of the Supreme Arbitration Court of the Russian Federation pointed out that the deadlines for the fulfillment of such requests should take into account the real possibility of a joint-stock company to do this without disrupting the legal entity's work regime. Attention is drawn to the information letter of the Supreme Arbitration Court of the Russian Federation (Information letter of the Presidium of the Supreme Arbitration Court of the Russian Federation dated January 18, 2011 N 144, 2011; Information letter of the Presidium of the Supreme Arbitration Court of the Russian Federation dated January 18, 2011 N 144, 2011; Information letter of the Presidium of the 
Supreme Arbitration Court of the Russian Federation dated January 18, 2011 No. 144, 2011; Information letter of the Presidium of the Supreme Arbitration Court of the Russian Federation dated January 18, 2011 N 144, 2011).

Judicial practice is experienced in satisfying shareholders 'claims on receiving information from the past five years. It is during this period that the company keeps the documents. It is possible, in our opinion, to propose the inclusion in the Federal Law on JSC a provision on accessibility in the last five years of work. A longer period should be accompanied by an explanation of the purpose and motives of the shareholder.

A special case of Teaching of the right is a request for documents in which a trade secret is hidden. After all, there is always the danger of disclosing the information received. Moreover, this can be done both intentionally and through carelessness due to careless storage. Therefore, joint stock companies do not very often carry out such requests for information.

Such cases are easily resolved in the courts if there is evidence that the shareholder is not a bona fide person who has previously disclosed a trade secret. But it is very difficult to do in the absence of goals and harmful intent of the shareholder.

Shareholders are required to keep confidential documents about the activities of the organization in secret. According to the position of the Presidium of the Supreme Arbitration Court, expressed in the information letter dated January 28,2011 . "On some issues of the practice of arbitration courts considering disputes on providing information to participants of business societies" has the right to require writing a receipt-obligation to keep the confidential information received in secret.

However, the legislation does not indicate the relationship of such a receipt with the obligation of the shareholder to keep information secret. Meanwhile, as a result of disclosure of information containing a commercial secret, a joint-stock company may incur very serious losses. Their shareholder is obliged to compensate in accordance with Article 1472 of the Civil Code of the Russian Federation. Meanwhile, it is extremely difficult to prove that this information was disclosed by this shareholder.

A few words should be said about the Teaching of the right to information at the place of familiarization with it. According to the legislation, the requested documents are provided to the shareholder for examination at the company's premises.

However, such premises may be residential real estate, as registration can be implemented, according to paragraph 4 of the Resolution of the Presidium of the Supreme Arbitration Court of the Russian Federation of July 30, 2013 No. 61 "On some issues of the practice of resolving disputes related to the accuracy of the address of a legal entity" (Resolution of the Plenum of the Supreme Arbitration Court of the Russian Federation of July 30, 2013 N 61). Consequently, the shareholder requesting information can expect to get acquainted with the information in this room. It would be correct, in our opinion, to give freedom of choice to the executive bodies of the joint-stock company in the premises in which the shareholder will get acquainted with the documents. This information can be posted on the site of the joint stock company. Regarding the terms of familiarization, it should be noted that the shareholder can get acquainted with the documents he needs as long as he wishes, since the law does not regulate this period. A shareholder may delay the return of documents. Therefore, the term must have a reasonable activity, justified by the object provided by the information. Such a rule can be included in the legislation: the period for familiarization is set based on the volume of the documents provided and can be extended at the request of the shareholder.

\section{Conclusions}

As a rule, the Teaching of the right to information is a prepared stage for further actions, including complaints to law enforcement agencies, filing claims with the court, mercenary use of information, harm and causing damage to society.

Domestic legislation does not define the concept of "corporate blackmail". The issues of its fixation and the mechanisms of prevention, the establishment of the amount of damage caused to the company, its shareholders, the responsibility of the subjects-shareholders exercising their rights not in good faith are also settled. Corporate blackmail is not limited to this type of behavior. However, as highlighted in the scientific literature, in the conditions of the arbitration proceedings can commit Teaching of law in the case of treatment of a minority shareholder with a claim in the courts, but the courts do not meet the claims of minority shareholders alleging claims, intending to cause harm to the public limited company does not rely on Article 10 of the Civil Code, do not apply it (Tarasov, 2000).

First of all, such actions threaten the joint-stock company that does not have well-established legal and economic security services, they don't have a corporate lawyer, or an organizational basis for development. But corporate 
blackmail can potentially be subjected to every joint stock company that has minority shareholders. After all, potentially even the owner of one share can Teaching its rights as a shareholder, and unfairly use his powers, which he possesses by virtue of his affiliation. Therefore, in the domestic economic space, most joint-stock companies seek to get rid of minority shareholders. This action is possible due to the opportunity provided by law for the forced redemption of shares from minority shareholders in accordance with article 84.8 of the Federal Law "On Joint Stock Companies" by a major shareholder.

However, the application of this provision is determined by the objectives of a number of requirements, among which: a shareholder who wants to buy back shares must have at least $95 \%$ of the shares independently or with affiliates. The exercise of the right of compulsory redemption is subject to difficult conditions and high costs on the part of the shareholder who purchases shares.

As already mentioned, one of the most common cases of Teaching of the right to information is a situation when a joint stock company receives requests for information from shareholders whose demands for copies are significantly complicate the work of the joint stock company. Some scientists allow themselves to determine the situation of Teaching of the right: these are cases where a shareholder who has $0.1 \%$ of shares requests a list of documents stipulated by art. 89, 91 of the Federal Law "On JSC" and Art. 6 of the Federal Law "On the Protection of the Rights and Lawful Interests of Investors in the Securities Market". From the point of view of a number of scientists, only subjectively and individually it is possible to establish the existence of a fact of Teaching of the right, since the same requirements addressed to RAO UES and the unknown JSC Khlebokombinat X, suggest different efforts for their implementation. Thus, the scientist believes: "a sign that separates corporate blackmail from the normal activities of a joint stock company is the actions of shareholders, due to the subjective characteristics of a certain joint-stock company, creating for it such objective difficulties in its activities that give the company and its shareholders a certain public danger. "

A shareholder may request documents for a short time. In this case, if the documents are the same, then this indicates and indicates that the shareholder has no special interest, but implements it. Meanwhile, his claim can be defined as Teaching of the right. However, the Federal Law "On Joint Stock Company" itself does not imply such a basis for refusing to transfer copies of documents. The repetition and frequency of its request is important for failure. Teaching of law is a reason for refusal. According to D.V. Gololobova: "It cannot be recognized as an Teaching of the right "to receive information about a joint-stock company" for its communication to official controlling and supervisory bodies in order to create negative consequences for the company in relations with them. The shareholder has an interest in the fact that the joint-stock company works and makes a profit in compliance with the current legislation".

\section{Acknowledgement}

This article was prepared with the financial support of the RFBR grant No. 19-011-00820 (a) "The legal policy of the Russian State, its priorities and principles in the digital economy and the digital technological structure: conceptual, methodological, sectoral aspects of digitalization of law and legal regulation"

\section{References}

Akimzhano, T., Amandykova, S., Tleukhan, R., Daurembekov, Y. \& Aykumbekov, N. (2018). Problems of applying and realization of preventive measures in the form of detention concerning persons, suspected and accused in the commission of the act of terrorism and crimes of extremist nature. Opción, 34(85-2), 800-823.

Federal Law of 05.03.1999 N 46-FZ (as amended on 07.23.2013). On the protection of the rights and legitimate interests of investors in the securities market. Russian Newspaper. 03.11.1999, 46.

Federal law of 08.02.1998 N 14-FZ (as amended on 12/29/2015). On limited liability companies. Rossiyskaya Gazeta, 30, 17.02.1998.

Federal Law of December 26, 1995 No. 208-FL. (1996). On Joint-Stock Companies. Collected legislation of the Russian Federation, 1, Article 91.

García-Santillán, A. (2019). An Algorithm to Renegotiate Debt through Equivalent Equations and Transaction Costs: A Proposal for the Field of Financial Education. International Electronic Journal of Mathematics Education, 14(1), 123-136. https://doi.org/10.12973/iejme/3981

Information letter of the Presidium of the Supreme Arbitration Court of the Russian Federation dated January 18, 2011 N 144. (2011). On some issues of the practice of arbitration courts considering disputes on providing 
information to participants of economic societies. Bulletin of the Supreme Arbitration Court of the Russian Federation, 3.

Jaramillo, L. E. S. (2018). Malware Detection and Mitigation Techniques: Lessons Learned from Mirai DDOS Attack. Journal of Information Systems Engineering \& Management, 3(3), 19.

Kolosovskaya, T. V. \& Zharkaya, O. A. (2015). Actual issues of Teaching of rights by minority shareholders, Security of business, 4, 16-20.

Krokhina, M. S. (2015). Shareholder's right to information: implementation and Teaching. Law and Economics, 7 , 59-66.

Kuzubov, A. A., Shashlo, N. V., Petruk, G. V. \& Korostelev, A. A. (2018). Developing a supply chain subsystem to manage the process of obstacle elimination for the innovative development of business entities. International Journal of Supply Chain Management, 7(5), 621-631.

Lee, J. W. \& Cormier, J. F. (2010). Effects of consumers' demographic profile on mobile commerce Adoption. Journal of Distribution Science, 8(1), 5-11.

Millanei, A., Ghabooli Dorafshan, S. M. H. \& Bayrami, A. (2016). Sunnite Religious View about Jurisprudence Nature of Istisna Contract. UCT Journal of Social Sciences and Humanities Research, 4(1), 25-27.

Resolution of the Federal Arbitration Court of the Moscow District of March 6, 2012 in case No. A41-21750 / 11. SPS Consultant Plus.

Resolution of the Federal Arbitration Court of the Volga Region dated December 27, 2013 in case No. A55-5450 / 2013. SPS Consultant Plus.

Resolution of the Federal Arbitration Court of the West Siberian District of March 9, 2011 in case No. A45-25123. (2009). SPS ConsultantPlus.

Resolution of the Plenum of the Supreme Arbitration Court of the Russian Federation of July 30, 2013 N 61 "On some issues of the practice of dispute resolution related to the accuracy of the legal entity's address". SPS "Consultant Plus".

Tarasov, I. T. (2000). The Doctrine of Joint-Stock Companies. M.: Statute, 2000, 444. 